Portland State University

PDXScholar

\title{
May Issue vs. Shall Issue Concealed Carry Laws: an Exploration of the Breakdown of Crime, Victim Relationship and Location
}

\author{
Patrick R. Mazzella \\ Portland State University \\ Christopher Carey \\ Portland State University
}

Follow this and additional works at: https://pdxscholar.library.pdx.edu/honorstheses Let us know how access to this document benefits you.

\section{Recommended Citation}

Mazzella, Patrick R. and Carey, Christopher, "May Issue vs. Shall Issue Concealed Carry Laws: an Exploration of the Breakdown of Crime, Victim Relationship and Location" (2019). University Honors Theses. Paper 705.

https://doi.org/10.15760/honors.722

This Thesis is brought to you for free and open access. It has been accepted for inclusion in University Honors Theses by an authorized administrator of PDXScholar. Please contact us if we can make this document more accessible: pdxscholar@pdx.edu. 


\title{
May Issue vs. Shall Issue Concealed Carry Laws: an Exploration of the Breakdown of Crime, Victim Relationship and Location
}

\author{
By: Christopher Carey, Patrick Mazzella
}

\begin{abstract}
This thesis takes an exploratory look at shall issue and may issue concealed carry laws using a comparative study with a sample of may issue states and shall issue states. The comparison is done over 3 sections: general crime rate, location of incidents and victim relationship to the offender. While the study found some patterns significant within the data, the lack of sufficient sample size severely limits the weight of anything found. Within the data, however, the study found a possible relationship between shall issue states and a higher percentage of romantic partner offenders, and a higher percentage of offenses in shops in stores. The study also found a potential relationship between may issue states and a higher percentage of offenders who were strangers to the victim and a higher percentage of incidents out in the street or alleys or inside a house/domicile.
\end{abstract}


Christopher Carey

Patrick Mazzella

\section{May Issue vs. Shall Issue Concealed Carry Laws: an Exploration of the Breakdown of Crime, Victim Relationship, and Location}

Introduction

As of the time of writing, the United States debates over gun rights and laws, with party lines and political beliefs dividing the opinions of Americans. This divide also extends to academia, with scholarship often arguing in favor or in disfavor of the free armament of the general populace (La Valle 2013). However, much of this scholarship uses biased methodology, overstates their results, or fails to establish conditions of causality or causal order (Kleck, 2015). Kleck found that of 90 studies done within the discourse community, only 4 contained validated measures of gun prevalence, established causal order, and controlled for significant variables.

This divide in research has also resulted in the majority of public and scholarly focus for study being on violence rates vs gun prevalence and/or laws surrounding firearms and armed populaces. As a result, extra focus has been shown the specific study of concealed carry laws, and their effect on crime rates. This specific subsection of study also tends to focus primarily on violent crime rates and exclude other types of crime, to the exclusion of other elements of crime, and demographics.

Shall and may issue concealed carry laws have been a point of study within the community, due to the movement of state legislature towards shall issue concealed carry, and away from may issue (Grossman \& Lee, 2008). Grossman and Lee (2008) provide a consistent method for determining the concealed carry law status of a jurisdictional area. Concealed carry laws are divided into four sections, no-issue, no permit/ no requirements, shall issue and may issue. No-issue states are states that have no laws in place allowing for citizens to carry a weapon concealed. No permit states are states that have no legislation requiring citizens to possess a permit in order to carry a weapon concealed. Shall issue states require citizens to meet certain requirements and if the citizen does, they are issued a concealed carry permit. Lastly, may issue states have requirements that must be met, like shall issue states, but they also have the citizen state good cause, or a reason they wish to possess a concealed carry permit, and the state authority has the agency to deny issuing a permit even if all the requirements have been met.

This thesis will focus on exploring differences in crime rate, victim-offender relationship and location of incident, comparing shall issue and may issue states. As this study is exploratory, with a limited sample the data and conclusions of this thesis are highly limited. Significantly, this study is NOT 
showing or attempting to find causality, only looking for potential correlation. However, even potential correlation is limited, as the sample size is limited by there only being two may issue states (Delaware and Rhode Island) using the coding and reporting system that the data was gained from.

Methods

For the analysis, the NIBRS (National Incident-Based Reporting System) was chosen as the resource data was gained from ( data directly downloaded from https://crime-dataexplorer.fr.cloud.gov/downloads-and-docs ). The NIBRS possesses several elements that make it suited for this form of exploratory comparative research. Chief among them are the scope of the NIBRS, and the consistency of coding. The NIBRS comes from the FBI Uniform Crime Report (UCR) and is an upgrade from the older summary reporting system (SRS). The NIBRS contains information about potential multiple offenses per incident, types and worth of property involved, drug use, victim-offender relationship, location, time of day and many more variables useful for an exploratory study such as this. Furthermore, all the data uses one coding scheme across the nation, allowing for less complicated and more accurate comparative data analysis.

At the inception of this study, the initial plan was to use California and/or New York as samples for may issue states. However, it was found that all may issue states (barring Rhode Island and Delaware) were in the testing phase of the NIBRS or had no plans of using the NIBRS. Regardless, Only Rhode Island and Delaware had released NIBRS reports. An attempt was made to gain local data from California and re-code it into an NIBRS format, however disparity in coding scheme between agencies, lack of consistent data fields and the huge number of localities and incidents, made further attempts non-feasible considering time constraints and comparability of data. This severely limits the generalizability of the may issue sample, seeing as the may issue sample states only consist of 2, small, new england states. Choosing may issue states was more involved with care paid to the variability of permissibility between the shall issue states and the location with respect to culture. Texas was chosen as a permissive shall issue state, Illinois was chosen as a more restrictive shall issue state and Connecticut and Pennsylvania was due to their status as New England shall issue states.

Each state's data was compiled into workbooks containing their data on individual sheets. Specific sheets were then moved to a master workbook, combined and then analyzed. Analysis consisted of combining the data, adding new columns with calculations specific to the question being answered, and putting the data into a pivot chart, allowing the data to be quickly observed.

For the crime rate, Offenses data was organized such that the coding system for the type of crime was translated into the non-coded equivalent with an additional column to detail whether it was a person crime, property crime, or crime against society. An example of this is the numerical code 27, which is translated to aggravated assault, which is a person crime. Each state had this data pivoted with the data being compiled into a count of each type of crime, with a calculation for crime rate per 100,000 using census data to calculate for the 2017 population of each state. Each states current pivot table had it's analyzed crime rate data compiled and averaged in a master pivot table comparing may issue states to shall issue ones, which was then sliced per type of crime (person, property, society). Another calculation was added to the pivot detailing percent change between shall issue and may issue states for each individual offense and whether the data was representing a shall issue or may issue state. 
For location, Offense data (which includes location) was organized with the type of crime, and the location of incident was translated from the numerical code to the non-coded equivalent. This data individual state data was compiled onto a single sheet and additional calculations were added for the issuance status of the state. The data was then pivoted and examined, with the count of each incident involving a specific location was shown as a percentage of the issuance status being represented (shall and may issue).

Victim relationship to offender was done in much the same way as location, except with the specific victim relationship data being used. The data was compiled in much the same way, with calculations added for the issuance status of the state and translations from the numerical code to the non-coded equivalent. The data was then pivoted and examined, with the count of incidents involving a specific relationship to the offender, shown as a percentage of the issuance status being represented.

Results

The analysis begins with the crime rate data. This data is to be considered the weakest of the data set which can be explained by the large differences in population between the may issue and shall issue state, as well as there only being 2 may issue states to create an average. This has resulted in some large crime rates for the may issue state sample and accordingly, large percent changes between shall and may issue crime rates.

Beginning with Property crimes. While the data shows uncommonly high rates of change, the data that shows the largest rates of change are stolen property offenses (1033\% higher in may issue states), False pretense/ swindle/ confidence game (991\% higher in may issue states) Embezzlement (875\% higher in may issue states) and theft from building (719\% higher in may issue states). If these

\begin{tabular}{|c|c|c|c|}
\hline \multirow[t]{2}{*}{ Property Crimes } & \multicolumn{3}{|c|}{ Average Rate Per 100 Thousand } \\
\hline & May-Issue & Shall-Issue & $\%$ Change \\
\hline Destruction/Damage/Vandalism of Property & 937.76 & 151.89 & $517 \%$ \\
\hline All Other Larceny & 389.41 & 128.90 & $202 \%$ \\
\hline Theft From Motor Vehicle & 424.89 & 98.21 & $333 \%$ \\
\hline Shoplifting & 405.39 & 88.27 & $359 \%$ \\
\hline Burglary/Breaking \& Entering & 360.12 & 70.84 & $408 \%$ \\
\hline Theft From Building & 352.04 & 43.00 & $719 \%$ \\
\hline False Pretenses/Swindle/Confidence Game & 275.39 & 25.23 & $991 \%$ \\
\hline Motor Vehicle Theft & 140.00 & 46.75 & $199 \%$ \\
\hline Credit Card/Automated Teller Machine Fraud & 99.98 & 29.51 & $239 \%$ \\
\hline Identity Theft & 81.00 & 11.07 & $632 \%$ \\
\hline Impersonation & 73.34 & 22.93 & $220 \%$ \\
\hline Theft of Motor Vehicle Parts or Accessories & 74.18 & 19.28 & $285 \%$ \\
\hline Robbery & 79.54 & 15.43 & $415 \%$ \\
\hline Counterfeiting/Forgery & 61.93 & 18.27 & $239 \%$ \\
\hline Stolen Property Offenses & 71.68 & 6.33 & $1033 \%$ \\
\hline Wire Fraud & 14.19 & 7.18 & $98 \%$ \\
\hline Embezzlement & 26.09 & 2.68 & $875 \%$ \\
\hline Arson & 13.47 & 1.74 & $672 \%$ \\
\hline Theft From Coin-Operated Machine or Device & 1.67 & 2.79 & $68 \%$ \\
\hline Pocket-picking & 2.49 & 1.66 & $50 \%$ \\
\hline Purse-snatching & 2.14 & 1.10 & $94 \%$ \\
\hline Extortion/Blackmail & 3.19 & 0.51 & $522 \%$ \\
\hline Hacking/Computer Invasion & 0.76 & 0.47 & $62 \%$ \\
\hline Welfare Fraud & 0.85 & 0.28 & $202 \%$ \\
\hline Bribery & 0.31 & 0.06 & $444 \%$ \\
\hline
\end{tabular}


crime rate changes were showing up in a data set, devoid of the sampling selection inhibitions of this data, an explanation for the percentage change could be attributed to these crimes nature as rational crimes. And concealed weapons sometimes act in a preventative manner when sufficient guardianship is in question (La Valle \& Glover, 2011). Sufficient guardianship being one of the three-part formulae of routine activities theory (Cohen \& Felson, 1979).

With society crimes, we see some high rates of change once again, however, due to the nature of concealed carry being very much a tool against crimes targeted against a person/ persons or their property, I tentatively find it unlikely that these laws will affect society crime rates. That being said, there is very little scholarship surrounding the effect of concealed carry, or even gun prevalence, on crimes against society, so more scholarship is needed to confirm or disprove that. However, this section holds consistently the highest rates of change, with many over $1000 \%$ and the highest of the entire data set, animal cruelty at a percent change of $24,505 \%$ higher in the may issue states.

\begin{tabular}{|lccr|}
\hline Society Crimes & Average Rate Per 100 Thousand \\
& & & \\
& May-Issue & Shall-Issue & $\%$ Change \\
\hline Drug/Narcotic Violations & 587.78 & 109.28 & $438 \%$ \\
Drug Equipment Violations & 186.59 & 46.98 & $297 \%$ \\
Weapon Law Violations & 152.21 & 19.86 & $666 \%$ \\
Animal Cruelty & 96.65 & 0.39 & $24505 \%$ \\
Pornography/Obscene Material & 23.40 & 2.04 & $1047 \%$ \\
Prostitution & 7.12 & 0.88 & $713 \%$ \\
Operating/Promoting/Assisting Gambling & 5.68 & 0.06 & $9675 \%$ \\
Betting/Wagering & 3.55 & 0.23 & $1449 \%$ \\
Purchasing Prostitution & 1.72 & 0.01 & $12071 \%$ \\
Assisting or Promoting Prostitution & 1.20 & 0.39 & $206 \%$ \\
Gambling Equipment Violation & 0.57 & 0.03 & $1682 \%$ \\
Sports Tampering & 0.10 & & $100 \%$ \\
\hline
\end{tabular}

Concerning person crimes, we once again must reiterate (as with all the crime rate data) that the lack of generalizability and internal validity due to the small and limited may issue sample makes conclusions of this data to be incredibly thin, if at all relevant. However, this data has one extremely interesting point of data. Justifiable homicide is the only offense on this list of offenses that possesses no blame on the perpetrator. Furthermore, it possesses the highest rate of change of all the person crimes at $1,274 \%$ higher in may issue states. Person crimes also possess a section where the crime rate was higher in the shall issue states, this crime is incest. 


\begin{tabular}{|lccr|}
\hline Person Crimes & Average Rate Per 100 Thousand & \\
& & & \\
& May-Issue & Shall Issue & $\%$ Change \\
Simple Assault & 811.93 & 133.31 & $509 \%$ \\
Intimidation & 165.34 & 52.79 & $213 \%$ \\
Aggravated Assault & 186.25 & 26.45 & $604 \%$ \\
Fondling & 37.30 & 6.78 & $450 \%$ \\
Rape & 28.92 & 5.95 & $386 \%$ \\
Kidnapping/Abduction & 15.28 & 2.63 & $481 \%$ \\
Sodomy & 6.79 & 0.87 & $682 \%$ \\
Statutory Rape & 3.38 & 1.50 & $126 \%$ \\
Sexual Assault With An Object & 3.87 & 0.85 & $357 \%$ \\
Murder and Nonnegligent Manslaughter & 3.71 & 0.55 & $573 \%$ \\
Human Trafficking, Commercial Sex Acts & 0.58 & 0.14 & $315 \%$ \\
Justifiable Homicide & 0.94 & 0.07 & $1274 \%$ \\
Incest & 0.20 & 0.37 & $85 \%$ \\
Negligent Manslaughter & 0.10 & 0.09 & $22 \%$ \\
Human Trafficking, Involuntary Servitude & 0.09 & 0.02 & $300 \%$ \\
\hline
\end{tabular}

Location data is an important area to examine, as the places in which incidents happen can give those studying crime, clues as to why they were chosen by the offender. In the scope of concealed weapons laws, location is significant as it can speak to where crimes are committed and where do the rates change between shall and may issue jurisdictions. the Location data is the first data set that shows some similarity between shall and may issue states with some key differences. This is very important as (unlike the crime rate data) it shows specific areas of difference amongst a majorly similar data set allowing for identification of key differences, and a greater assumption of comparability. The first significant difference, is the increased frequency of department stores/shops grocery stores, motels and parking garages as the sites of incidents in shall issue states. The second significant difference is the increased rate of incidents involving streets/sidewalks/alleys, government/public buildings and inside the home. The rest of the data was fairly consistent adding validity to this data. I could find next to no scholarship about the effect of armed citizens on location of incident. However, using the routine activities theory ( Cohen \& Felson, 1979), I would tentatively say that it appears as if prevalence of firearms is acting as a protective factor in areas where people are more fortified (domicile) or on guard (highway/street/alley). Interestingly, that does not fit with the high rate of incidents in parking garages in shall issue states.

\begin{tabular}{|lcc|}
\hline \multicolumn{1}{|c|}{ Location } & \% of Incidents with location \\
\hline Abandoned/Condemned Structure & May & Shall \\
Air/Bus/Train Terminal & $0.06 \%$ & $0.05 \%$ \\
Amusement Park & $0.16 \%$ & $0.21 \%$ \\
Arena/Stadium/Fairgrounds/Coliseum & $0.01 \%$ & $0.10 \%$ \\
ATM Separate from Bank & $0.03 \%$ & $0.07 \%$ \\
Auto Dealership New/Used & $0.04 \%$ & $0.07 \%$ \\
\hline
\end{tabular}




\begin{tabular}{|c|c|c|}
\hline Bank/Savings and Loan & $0.85 \%$ & $0.96 \%$ \\
\hline Bar/Nightclub & $0.86 \%$ & $0.67 \%$ \\
\hline Camp/Campground & $0.04 \%$ & $0.03 \%$ \\
\hline Church/Synagogue/Temple/Mosque & $0.30 \%$ & $0.31 \%$ \\
\hline Commercial/Office Building & $2.03 \%$ & $1.89 \%$ \\
\hline Community Center & $0.15 \%$ & $0.07 \%$ \\
\hline Construction Site & $0.18 \%$ & $0.62 \%$ \\
\hline Convenience Store & $2.15 \%$ & $2.49 \%$ \\
\hline Cyberspace & $0.17 \%$ & $0.18 \%$ \\
\hline Daycare Facility & $0.05 \%$ & $0.07 \%$ \\
\hline Department/Discount Store & $4.72 \%$ & $5.54 \%$ \\
\hline Dock/Wharf/Freight/Modal Terminal & $0.04 \%$ & $0.03 \%$ \\
\hline Drug Store/Doctor's Office/Hospital & $1.74 \%$ & $1.22 \%$ \\
\hline Farm Facility & $0.01 \%$ & $0.05 \%$ \\
\hline Field/Woods & $0.38 \%$ & $0.31 \%$ \\
\hline Gambling Facility/Casino/Race Track & $0.64 \%$ & $0.12 \%$ \\
\hline Government/Public Building & $1.57 \%$ & $0.70 \%$ \\
\hline Grocery/Supermarket & $1.55 \%$ & $2.35 \%$ \\
\hline Highway/Road/Alley/Street/Sidewalk & $19.31 \%$ & $15.72 \%$ \\
\hline Hotel/Motel/Etc. & $1.10 \%$ & $1.65 \%$ \\
\hline Industrial Site & $0.14 \%$ & $0.12 \%$ \\
\hline Jail/Prison/Penitentiary/Corrections Facility & $0.15 \%$ & $0.28 \%$ \\
\hline Lake/Waterway/Beach & $0.13 \%$ & $0.05 \%$ \\
\hline Liquor Store & $0.37 \%$ & $0.20 \%$ \\
\hline Military Installation & $0.00 \%$ & $0.00 \%$ \\
\hline Other/Unknown & $2.53 \%$ & $4.51 \%$ \\
\hline Park/Playground & $0.92 \%$ & $0.82 \%$ \\
\hline Parking/Drop Lot/Garage & $4.30 \%$ & $8.64 \%$ \\
\hline Rental Storage Facility & $0.19 \%$ & $0.44 \%$ \\
\hline Residence/Home & $44.47 \%$ & $41.14 \%$ \\
\hline Rest Area & $0.01 \%$ & $0.02 \%$ \\
\hline Restaurant & $1.77 \%$ & $1.91 \%$ \\
\hline School/College & $0.27 \%$ & $0.52 \%$ \\
\hline School-College/University & $1.00 \%$ & $0.39 \%$ \\
\hline School-Elementary/Secondary & $1.88 \%$ & $1.63 \%$ \\
\hline Service/Gas Station & $0.96 \%$ & $0.97 \%$ \\
\hline Shelter-Mission/Homeless & $0.03 \%$ & $0.09 \%$ \\
\hline Shopping Mall & $0.52 \%$ & $0.39 \%$ \\
\hline Specialty Store & $2.06 \%$ & $2.01 \%$ \\
\hline Tribal Lands & $0.00 \%$ & $0.00 \%$ \\
\hline
\end{tabular}


Next is the victim relationship to offender data. Similarly to location data, this is important to know, as it can show us what the differences in concealed carry laws, may have on who is choosing to victimize who. This data set also shows some internal validity, with many of the comparison values being statistically similar, and a couple of areas of difference. The first pattern noticed was the high percentage of incidents where the offender was a stranger or otherwise known statuses in the may issue states, and the offender was a romantic partner in the shall issue states. This both ties in remarks of firearms being a protective factor (Olson \& Maltz, 2001) (La Valle, 2013)( Grossman \& Lee 2008), and an aggravating factor for violence (La Valle 2013) (La Valle 2011) (Grossman \& Lee 2008).

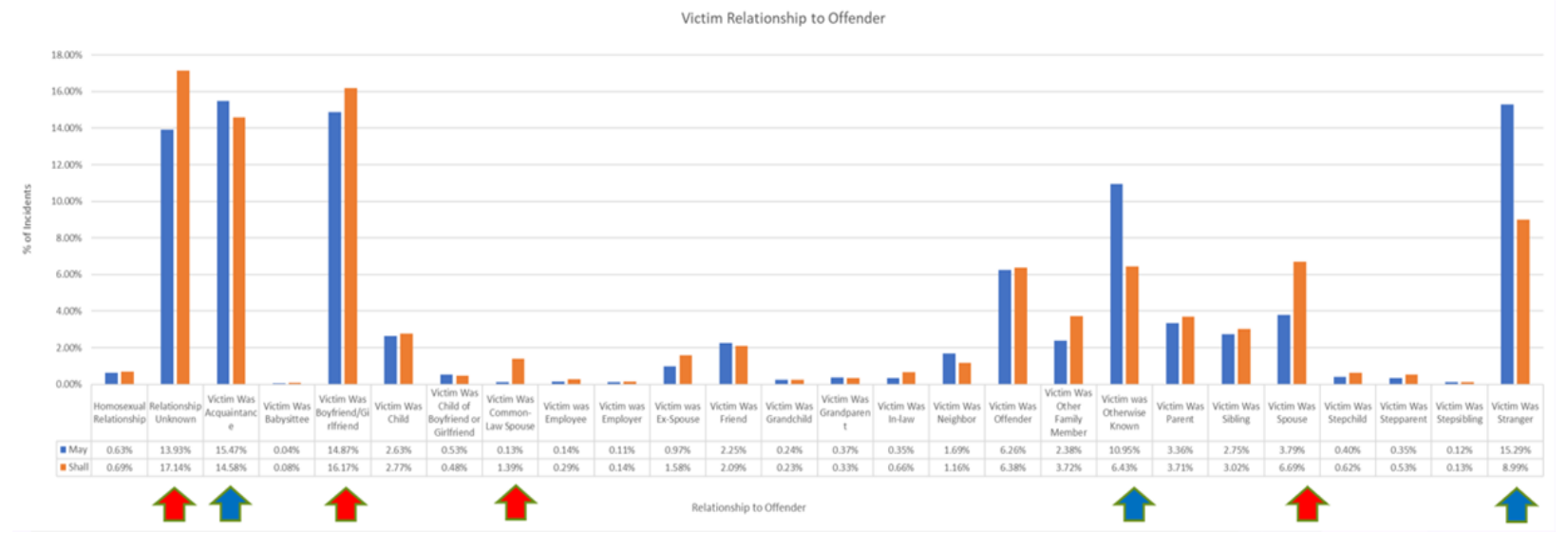

\section{Conclusions}

This thesis has aimed to explore the differences in shall issue concealed carry jurisdictions compared to may issue jurisdictions. Limitations in sample size, especially in may issue states, have resulted in a data set that is too small to honestly or morally speak to any correlations without overstating the results and significance of the data. However, there were some trends that coincide with former research and would warrant further study, as well as there being insights for future study. The first order of business for further study would be to increase the may issue state sample size. At the very least until California (a large, may issue state) has released several yearly reports further searches for correlation in crime rate will be severely stunted. A multi-year, nationwide study of shall issue vs may issue concealed carry states and their trends would allow for a much better understanding of correlation between concealed carry laws, specific crime rates, victim types, and locations.

Of all my data, the incident location data and the victim relationship data is the strongest. And while I wouldn't state them as correlative these data sets, show some interesting patterns that should be explored more with the above-named improvements to the experiment. One pattern that deserves further exploration is the increased percentage of the victim being a stranger to the victim in may issue states, and a romantic partner in shall issue states. Not only should this be tested again with a more valid and generalizable sample, but if a trend shows itself to be consistent, examine what crimes make 
up these significant victim-offender relationships. A similar tactic could be taken with the locations. After proving a trend, start examining what crimes are most prevalent in these significant locations

\section{References}

Journals:

1. Cohen, L. E., \& Felson, M. (1979). Social Change and Crime Rate Trends: A Routine Activity Approach. American Sociological Review, 44(4), 588. doi:10.2307/2094589

2. Olson, D. E., \& Maltz, M. D. (2001). Right-to-Carry Concealed Weapon Laws and Homicide in Large U.S. Counties: The Effect on Weapon Types, Victim Characteristics, and Victim-Offender Relationships. The Journal of Law and Economics, 44(S2), 747-770. doi:10.1086/338345

3. Grossman, R. S., \& Lee, S. A. (2008). MAY ISSUE VERSUS SHALL ISSUE: EXPLAINING THE PATTERN OF CONCEALED-CARRY HANDGUN LAWS, 1960â?]"2001. Contemporary Economic Policy, 26(2), 198-206. doi:10.1111/j.1465-7287.2007.00094.x

4. La Valle, J. M. (2013). "Gun Control" vs. "Self Protection": A Case against the Ideological Divide. Justice Policy Journal, 10(1), 1-27

5. La Valle, J. M., \& Glover, T. C. (2011). Revisiting Licensed Handgun Carrying: Personal Protection or Interpersonal Liability? American Journal of Criminal Justice, 37(4), 580-601. doi:10.1007/s12103-011-9140-4

6. Kleck, G. (2015). The Impact of Gun Ownership Rates on Crime Rates: A Methodological Review of the Evidence. Journal of Criminal Justice,43(1), 40-48. doi:10.1016/j.jcrimjus.2014.12.002

Websites:

1. (n.d.). Retrieved from https://crime-data-explorer.fr.cloud.gov/downloads-and-docs

2. SRS to NIBRS: The Path to Better UCR Data. (2017, March 28). Retrieved from https://www.fbi.gov/services/cjis/cjis-link/srs-to-nibrs-the-path-to-better-ucr-data

3. US Census Bureau. (n.d.). Census.gov. Retrieved from https://www.census.gov/ 